\title{
Women Participation in Rural Tourism: A Case of Ella, Sri Lanka
}

\author{
DOI: https://doi.org/10.18196/agraris.v7i2.11294
}

\begin{abstract}
Tourism industry is one of sectors that have potential to develop and grow in the next few years in Sri Lanka. According to Tourism Development Strategy of Sri Lanka, tourism industry is expected to be the largest foreign exchange earner by 2024. The principal focus of this study was to explore major factors that affect women's participation and non-participation in the hospitality industry in Ella DS division Sri Lanka. The study used a deductive approach, and primary data were collected through a self-administered structured questionnaire. Samples were 60 women, consisting of thirty women involved in the hospitality industry and thirty women of the non-hospitality industry, randomly selected. Results were analyzed using descriptive statistics and inferential statistics. The results found that the differences in language skills and problem-solving had the most significant effect on women's participation in hospitality industry. Besides, childcare responsibility and lack of experience were affected women's involvement in this industry. The results also showed that most of the non-hospitality workers have language barriers (33.3\%), lack of knowledge about tourism industry (23.3\%), and lack of opportunities to engage in tourism work (13.3\%). Based on the results, $53.3 \%$ of 30 non-hospitality workers had an idea to be involved in tourism and hospitality industry in the future, while the remaining $46.6 \%$ had no idea to be involved.
\end{abstract}

Keywords: Barriers, gender, glass ceiling, hospitality, rural tourism, women employability

\section{INTRODUCTION}

Tourism and hospitality industry plays a vibrant role in an economy, shaping the future of the nation (Aslam, Awang, \& Othman, 2014). Sri Lanka tourism is on the rise, and the related services, training, and labor supply are also on-demand (Hettiarachchi, De Silva, \& Sivashankar, 2015). This denotes that there are enough opportunities for unemployed to engage in the tourism sector. Women's involvement in tourism and travel sector was $10-11 \%$ in Sri Lanka (International Labor Organization, 2016). Tourism is an employment generator in many countries, which also creates a market for women's employment (Aytuğ \& Mikaeili, 2017; Hafçi, 2018). Tourism is important in creating new job opportunities as it is a labor-intensive 
a labor-intensive sector. Globally, $54 \%$ of the workforce in tourism is female, yet there are disparities in wages (World Tourism Organization, 2019). In developing countries, this disparity is worse. Women face disparities at both horizontal and levels in the labor market (Rinaldi \& Salerno, 2020).

Rural tourism promotes farm income through non-agricultural activities, employment opportunities for women, new skills for rural people, building the rural economy, protecting landscape and wildlife, and uplifting the essential services in rural areas (education, health, transport, retail), and slows rural to urban migration (Aytuğ \& Mikaeili, 2017). Rural tourism is an effective way of supporting women's labor force, as women appear in most rural activities, either directly or indirectly. Also, they are flagbearers of rural culture, authentic traditions, and cuisines. Women are considered as passive workforce in rural tourism. Thus, decent employment can be provided to these women by bringing them to the forefront (Aytug \& Mikaeili, 2017; Sanagustin-Fons, Lafita-Cortés, \& Moseñe, 2018).

Nevertheless, women face a multitude of problems and challenges in engaging in rural tourism activities. These include entering the industry, and some factors can affect their continuation in the industry. Further, external factors may also play a role in women's decision to engage in rural tourism. This research investigates the factors affecting the rural women to engage in the local tourism and hospitality industry. Furthermore, factors affecting their engagement, and barriers for their engagement, especially in rural tourism and homestays, are assessed. This study looks into the dynamics of women's involvement at various stages of the small tourism accommodations and restaurants. Which factors affect women's involvement and non-involvement in the tourism and hospitality industry? Further, we try to identify suitable strategies to increase women's involvement in tourism and hospitality industry. This study will add to discussion of gender and tourism, in context of rural tourism, with special relevance to Ella region in Sri Lanka. The implication of the study is that this will serve as a checklist for identifying issues women face in the region, thus could benefit regional policymakers and assist in evidence-based policymaking. Though other studies have focused on women in tourism in general, fewer studies focus on the problems of women in rural tourism. This paper, unlike the literature, compares the issues of women in tourism as well as those who are not in tourism in the same place in question.

\section{Issues In Women Involvement In Rural Tourism}

Many studies investigated issues in women engagement in rural tourism: Brazil (Duarte \& Pereira, 2018), India (Mohanty, Swain, \& Besra, 2018), Serbia (Cvijanović \& Gajić, 2020; Milena, Nataša, \& Snežana, 2019; Milicaa, Gordanaa, \& Milan, 2021), Turkey (Aytuğ \& Mikaeili, 2017; Hafçi, 2018), Georgia (Khartishvili, Muhar, Dax, \& Khelashvili, 2019), Greece (Koutsou, Notta, Samathrakis, \& Partalidou, 2009), Nepal (Palikhe, 2018), Sri Lanka (Aslam $\&$ Awang, 2015) and Emerging countries (Chant, 2005; Rinaldi \& Salerno, 2020). There is an agreement in literature, and most women and men have positive attitudes towards rural tourism. Duarte and Pereira (2018) further suggested that women were not supplementary for rural tourism but complementary, as they are the major stakes of rural tourism. Although they 
still received a lesser return or are not paid at all (Mohanty et al., 2018), female managers saw rural tourism development as a business opportunity for them (Milicaa et al., 2021). However, the general consensus from literature is that women's participation in rural tourism is not at a satisfactory level, mainly in emerging economies.

A wider array of employment opportunities is available for a range of people from educated to less educated, from urban to rural, for both men and women as well as for marginalized groups. Further, tourism sector provides very flexible employment opportunities, though they are vulnerable to external shocks. Ample studies had been conducted on employment-related issues in tourism for both formal and informal employment. These included issues in training staff or labor force (formal training and informal training), internships, and turnover (Wang, 2013; AlBattat \& Som, 2013; Zahari, Yusoff, Jamaluddin, Radzi, \& Othman, 2010; Yusoff, Zahari, Ahmad, Isa, \& Ghani, 2013; Gibbs \& Slevitch, 2019). These aspects had been studied based on gender perspectives as well. It was suggested that certain glass ceilings exist for women to engage in this sector (Maxwell, Ogden, \& Broadbridge, 2010). Though this was true for most other sectors, the existing glass ceilings were much greater in the hospitality industry (Janta, 2011; Knutson \& Schmidgall, 1999). Koutsou et al. (2009) discussed the issues of age, experience, and education of women shaping rural tourism engagements and also on risk-taking. Aged, experienced, and educated women tend to start their own businesses than join cooperatives, as they coukd handle the issues faced by the industry. Despite these issues, Cvijanović \& Gajić (2020) suggested that rural tourism empowers women through social connectivity. A similar finding stems from Greek women entrepreneurs involved in the agro-tourism business (Koutsou et al., 2009).

According to World Bank Group (2017), the main factors that explain women's participation in tourism are mainly personal and work-related factors (i.e., environment), as most of the gender constraints can be grouped within these groups. This study also mainly looks into the issues and problems of women's involvement in rural tourism, mainly based on these two cohorts. Though literature posits and studies women's involvement in rural tourism, no literature has paid attention to personal factors and environment-related factors. Thus this study adds to the literature filling this gap with evidence from Sri Lanka.

\section{RESEARCH METHOD}

This research investigates the Ella DS division of the Badulla district to study the women involved in the small-scale hospitality industry. Ella DS is located 200 kilometers away from Colombo with an altitude of 1,041 m above mean sea level. Ella has been a very famous tourist destination which is located in a remote rural area (Urban Development Authority, 2019). It is renowned for countryside tourism, especially for typical village life, scenery, waterfalls, peaks, hiking, and rich biodiversity. Thus there are numerous small and medium scale hospitality enterprises as well as large hotels. Since even the large-scale hotels are surrounded by nature, recreation activities, and villages, this area consists of many small-scale boutiques and restaurants which cater to tourists. Thus this place was deemed to be an ideal place to 
study the research question. The villagers, including the women, have the potential to serve the tourists through diverse means of business activities in Ella.

The study followed a deductive approach. Data were collected through a pre-tested interviewer-administered questionnaire from 60 women in Ella, with 30 women involved in the hospitality industry and 30 women who were not involved in the industry. This stratification would provide a better understanding of the push and pull factors for these women to engage in the hospitality industry. The questionnaire primarily consisted of 4 sections with categorical and Likert scale questions. A section of the socio-economic background (categorical questions), followed by Success factors of local women employability in tourism ( 5 points Likert scale: 1 = extremely important, 2 = Very important, $3=$ moderately important, 4 = slightly important, $5=$ Not at all important; Lower mean value denotes that factor is extremely important), pull factors of women participation ( 4 points Likert scale: 1 = very relevant, 2 =relevant, 3 = less relevant, $4=$ not relevant at all: Lower mean value denotes that factor is extremely important.), and strategies to improve local women participation in the hospitality industry (selection). The survey also included an in-depth discussion with selected respondents. The discussion helped in understanding the women's responses in a different context, and they were used to validate and explain the answers in the questionnaire. The data were analyzed using SPSS version 21 software. The analysis was performed using descriptive analysis and mean comparisons of selected variables and perception between women working in the tourism industry and women not involved in any of tourism-related activities. The conceptual framework of the study can be seen in Figure 1 .

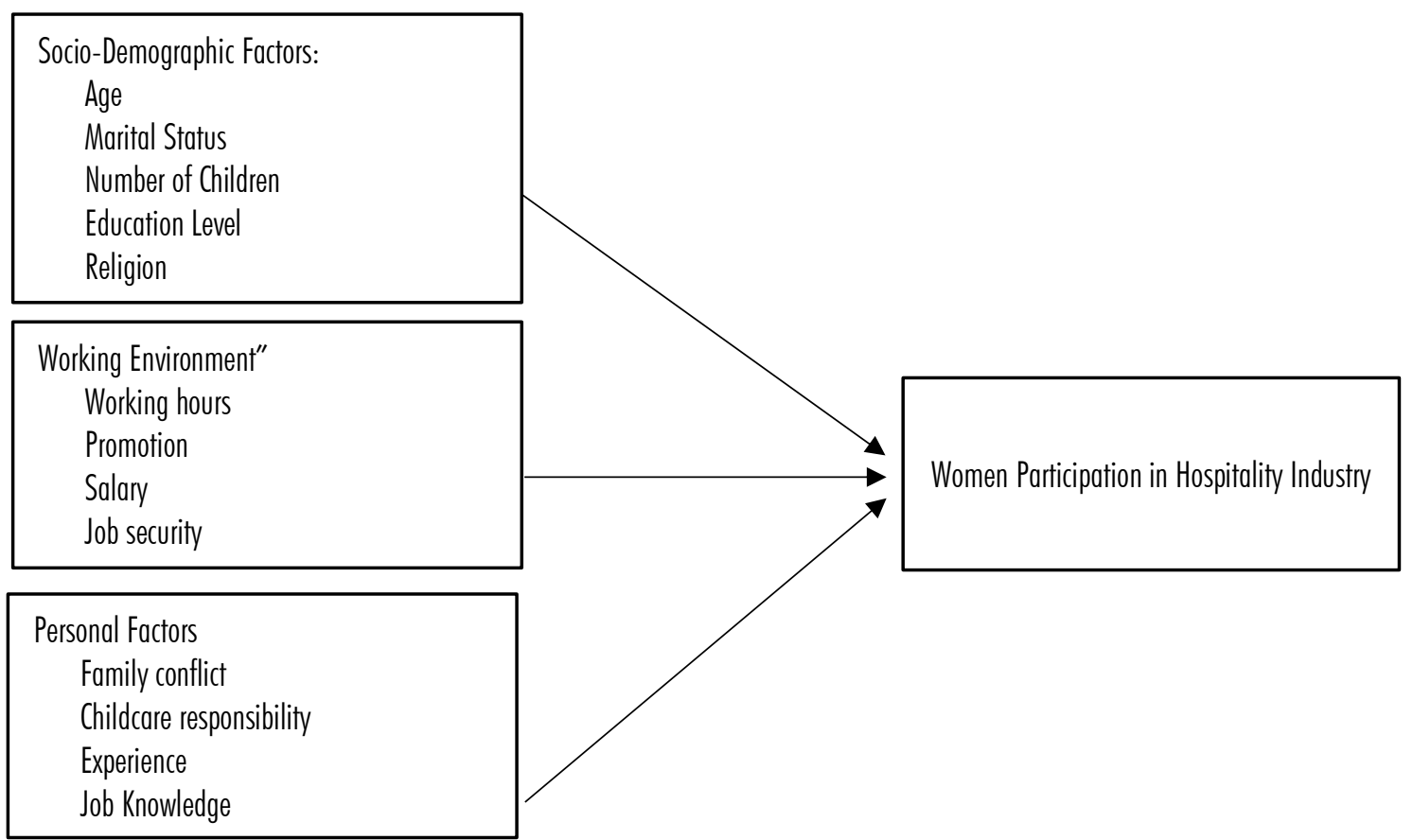

FIGURE 1. CONCEPTUAL FRAMEWORK FOR WOMEN INVOLVEMENT IN TOURISM AND HOSPITALITY RELATED WORK 


\section{RESULTS AND DISCUSSION}

\section{Sample Profile}

As mentioned, half of the sample was involved in the tourism and hospitality industry, and another half were not involved. When considering the women who work in the hospitality industry, the majority of women $(86.60 \%)$ were married, and $13.30 \%$ of women were unmarried among those who were involved in the industry. Among those who have not been involved in the industry, 63\% were married, and 37\% were unmarried (Table 1). This clearly suggests that most of the women engaged in the tourism and hospitality industry were married. This may be for many plausible reasons. In general, there is a taboo in society for women working in tourism-related income-generating activities. Thus, due to social status pressure, unmarried women may tend to be less interested in the job openings in this field. On the other hand, there may be other reasons for married women to engage in these activities. One is that, with family and children, the expenses of a household may be high, so women may also be pressured to work to support the family. Another reason could be that their male counterparts may already have engaged in tourism-related livelihoods, and women may be supporting their husbands in their ventures. On the other hand, it could also be true that, after marriage, women are less pressured to get their hands into the tourism industry. The societal pressure which was there before marriage could be absent after marriage.

Age distribution patterns were similar in both samples (Table 1). Nevertheless, the respondents were distributed well among the women who were involved in the tourism and hospitality industry compared to those who were not involved. In the former group, mostly women (30\%) were in the $25-29$ age group, and $23 \%$ were in the $45<$ age group (Table 1 ). Rests of them were $30 \%$ of women in the $30-34$ age category and $13 \%$ from the $35-39$ age category. So, most women were in the young age (25-29) and (30-34) age category (almost $37 \%$ ). This sums up that $70 \%$ of women were between 25 to 45 years old. The least representation of $7 \%$ was from women who were less than 25 years of age. So, there is the potential of enthusiasm and ability to get new job experience in the tourism and hospitality industry. In the latter group, the majority (36\%) of women were in the 25-29 age category, and $32 \%$ were in the $45<$ age category (Table 1 ). Only a few women represented the age group between 35 to 45 years in the women who were not involved. Nevertheless, even in the same age group, there was better representation from the women involved in the tourism and hospitality industry. This again may be explained as the groups involved in tourism-related activities are predominantly married. It is also possible that by chance, the other group had less representation from that age group.

There were no substantial differences in the groups with respect to educational qualifications though subtle differences were there. Women involved in tourism-related activities were almost educated, i.e., none of them were in the education category, whereas there were few from the not involved group. Also, the percentage of women who received higher education was slightly higher in those who were involved with the industry. Education is a good demographic factor for all the women who work in the tourism and hospitality 
industry, e.g., the ability to speak a different language is a good opportunity for them to succeed in their job. When comparing those two educational levels majority of them have secondary education (70\%), and only 30\% of women have diplomas and bachelor's degrees. In the not-involved group of women, $70 \%$ of women had secondary education, $23 \%$ had higher education, and the rest had only primary education. Some of these women work in government or private jobs, but some of them are housewives.

TABLE 1. DESCRIPTION OF THE SAMPLE PROFILE

\begin{tabular}{|c|c|c|c|}
\hline Variable & Category & $\begin{array}{l}\text { Women involved in the tourism and } \\
\text { hospitality industry }\left(\mathrm{N}_{1}=30\right)\end{array}$ & $\begin{array}{l}\text { Women not involved in tourism and } \\
\text { hospitality industry }\left(\mathrm{N}_{2}=30\right)\end{array}$ \\
\hline Age & $20-24$ & $7 \%$ & $7 \%$ \\
\hline mean age of both & $25-29$ & $30 \%$ & $36 \%$ \\
\hline \multirow[t]{7}{*}{ groups $=36.05$} & $30-34$ & $17 \%$ & $20 \%$ \\
\hline & $35-39$ & $13 \%$ & $3 \%$ \\
\hline & $40-44$ & $10 \%$ & $3 \%$ \\
\hline & $45<$ & $23 \%$ & $32 \%$ \\
\hline & & Avg. age $=35.8$ & Avg. age $=36.2$ \\
\hline & & Max. age $=69$ & Max. age $=60$ \\
\hline & & Min. age $=24$ & Min. age $=23$ \\
\hline \multirow[t]{2}{*}{ Marital Status } & Married & $86.6 \%$ & $63 \%$ \\
\hline & Unmarried & $13.3 \%$ & $37 \%$ \\
\hline \multirow[t]{5}{*}{ Educational level } & Primary & - & $7 \%$ \\
\hline & education & $70 \%$ & $70 \%$ \\
\hline & Secondary & $30 \%$ & $23 \%$ \\
\hline & education & & \\
\hline & Higher education & & \\
\hline \multirow[t]{8}{*}{ Level of employment } & Food and & $33.3 \%$ & These women were not involved in the \\
\hline & beverage & $13.3 \%$ & tourism and hospitality industry \\
\hline & Front office & $16.6 \%$ & \\
\hline & Finance & $10 \%$ & \\
\hline & Housekeeping & $3.3 \%$ & \\
\hline & & $23.3 \%$ & \\
\hline & management & & \\
\hline & Accommodation & & \\
\hline \multicolumn{2}{|c|}{ Number of family members (average) } & 3.7 & 3.9 \\
\hline \multicolumn{2}{|c|}{ Number of children(average) } & 1.6 & 2.05 \\
\hline \multirow{5}{*}{$\begin{array}{l}\text { Years in tourism } \\
\text { industry/ Experience }\end{array}$} & $1-5$ & $80 \%$ & These women were not involved in the \\
\hline & $6-10$ & $10 \%$ & tourism and hospitality industry \\
\hline & $11-15$ & $3 \%$ & \\
\hline & $16-20$ & - & \\
\hline & Above 20 years & $7 \%$ & \\
\hline
\end{tabular}

According to this research, the researchers found six main departments where women work in cafes and restaurants. Majority of them (33.3\%) work in the food and beverage department. Furthermore, the most minor participation $(3.3 \%)$ is found in event management.

In women worker families, the average family size was 3.7, and the average number of children was 1.6. In families where women are not involved in tourism, the average family size 
and number of children were 3.9 and 2.05, respectively. Most (80\%) of them have been involved in the tourism and hospitality industry within the last 1 to 5 years; about $10 \%$ have 6-10 years of experience in the industry. Nevertheless, only 7\% of women have above 20 years of job experience in the tourism industry.

According to the collected data for women workers, $16.6 \%$ of women said gender affects tourism jobs. Nevertheless, most of the women (60\%) said there was no gender barrier in getting jobs related to the tourism industry. However, $23.3 \%$ had a moderate idea about gender barriers.

When considering the idea of the women who are not involved in this sector, most of them $(43.3 \%)$ said there were gender barriers in tourism-related jobs. Also, 30\% of them said gender was not a big problem for this industry. Nevertheless, in this group, women who hold moderate views on gender barriers were around $26.6 \%$, which was significantly higher than the other group of women. Here, $13.3 \%$ of women said society had a good view about tourismrelated jobs. Furthermore, unfortunately, $30 \%$ of women said society had a bad view, and $56.6 \%$ said society had a moderate view regarding tourism and hospitality industry jobs.

Women perception about factors influencing the local women's employability in the hospitality industry

This section presents the perception of women regarding the factors that influence the success of a women's employability in the tourism and hospitality industry in Ella. These factors may differ between those who were engaged and those who were not engaged in this industry. Besides the factors that influence local women's employability of hospitality industry success, the distribution of 'obstacles to career success' was divided into two categories (Personal Factors and Working environmental factors) to analyze the different perceptions between the two samples clearly.

TABLE 2. KEY SUCCESS FACTORS FOR WOMEN EMPLOYABILITY IN THE TOURISM AND HOSPITALITY INDUSTRY

\begin{tabular}{|c|c|c|c|c|c|c|c|}
\hline & $\begin{array}{l}\text { Female } \\
\text { Hospitality }\end{array}$ & $\begin{array}{ll}\text { work in } \\
\text { dustry }\end{array}$ & $\begin{array}{l}\text { Female c } \\
\text { Hospitali }\end{array}$ & $\begin{array}{l}\text { not work in } \\
\text { dustry. }\end{array}$ & & & \\
\hline Factor & Mean & SD & Mean & SD & df & $t$ & Sig. \\
\hline Good Personality & 1.3333 & .71116 & 1.2667 & .63968 & 60 & .382 & .496 \\
\hline Effective communication skills* & & & & & & & \\
\hline $\begin{array}{l}\text { (Knowledge about different } \\
\text { languages) }\end{array}$ & 1.3667 & .55605 & 1.6333 & 1.03335 & 60 & -1.245 & .015 \\
\hline Attitudes towards work & 1.4333 & 67891 & 1.5000 & .82001 & 60 & -.343 & .620 \\
\hline Job Knowledge & 1.6333 & .92786 & 1.7333 & .82768 & 60 & -.441 & .562 \\
\hline Family support & 1.8000 & .96132 & 1.7667 & .81720 & 60 & .145 & .604 \\
\hline Hard work & 1.8667 & 1.16658 & 1.5667 & .72793 & 60 & 1.195 & .099 \\
\hline Problem-solving skills* & 1.8000 & .88668 & 2.0000 & .69481 & 60 & -.972 & .004 \\
\hline Job Security & 1.8333 & .98553 & 2.0333 & 1.40156 & 60 & -.639 & .113 \\
\hline Mentor Support & 1.8667 & .81931 & 2.3667 & .96431 & 60 & -2.164 & .493 \\
\hline Educational Qualification & 2.0667 & .98027 & 2.6667 & 1.12444 & 60 & -2.203 & .089 \\
\hline
\end{tabular}

Note: ${ }^{*} p<0.05$ means significantly different

The factors are presented from most important to least important (i.e., from low mean values to higher mean values) 
The perceptions on key success factors for women's employability in the tourism and hospitality industry did not differ greatly between the women who are involved and women who are not (Table 2). Mostly, both groups highlighted the same factors as important. In general, scores by women who were involved in the industry were low, meaning they mostly suggested all the factors were important compared to women who were not involved in the industry. The exception was the factors of familial support and hard work. For both these factors, not engaged women thought they were more important than those engaged with the industry.

Nevertheless, in general, both groups agreed that a good personality is the most important factor, effective communication skills and attitudes towards work. These were the most important three factors. Educational qualification was considered the least important factor by both groups of women. The next least important factors were mentor support and job security. Only in two factors, there were significant differences in the means, viz, effective communication skills and problem-solving skills. It is noteworthy that both of these two factors are skills that are usually considered very important in any working environment (Janta, 2011; Nyataya \& Ma, 2016).

TABLE 3. PULL FACTORS OF WOMEN PARTICIPATION IN TOURISM AND HOSPITALTY INDUSTRY

\begin{tabular}{|c|c|c|c|c|c|c|c|}
\hline \multirow[b]{2}{*}{ Personal Factors } & \multicolumn{2}{|c|}{$\begin{array}{l}\text { Female work in Hospitality } \\
\text { Industry }\end{array}$} & \multicolumn{2}{|c|}{$\begin{array}{l}\text { Female does not work in } \\
\text { Hospitality Industry. }\end{array}$} & \multirow[b]{2}{*}{ df } & \multirow[b]{2}{*}{$\mathrm{T}$} & \multirow[b]{2}{*}{ Sig. } \\
\hline & Mean & SD & Mean & SD & & & \\
\hline Conflicts with family activities & 2.2333 & .85836 & 1.6000 & .49827 & 60 & 3.495 & .075 \\
\hline Childcare responsibilities* & 2.4000 & 1.03724 & 1.5667 & .56832 & 60 & 3.859 & 0.002 \\
\hline Lack of experience* & 1.8667 & .97320 & 1.6333 & .49013 & 60 & 1.173 & 0.014 \\
\hline Inadequate job knowledge & 1.9667 & .85029 & 1.5667 & .50401 & 60 & 2.217 & 0.433 \\
\hline \multicolumn{8}{|l|}{$\begin{array}{l}\text { Factors related to Working } \\
\text { Environment }\end{array}$} \\
\hline Long working hours & 2.3333 & .88409 & 1.8000 & .71438 & 60 & 2.570 & .061 \\
\hline Lack of promotion & 2.1667 & .69893 & 2.0667 & .58329 & 60 & .602 & .246 \\
\hline $\begin{array}{l}\text { Satisfaction about salary than } \\
\text { other jobs (incentive, Bonus) }\end{array}$ & 1.9000 & .84486 & 1.9000 & .66176 & 60 & 0.000 & .375 \\
\hline
\end{tabular}

Table 3 presents the factors that act as barriers for women to involve in the tourism and hospitality industry. Contrastingly, compared to the push factors, there were considerable differences between the two women groups. Women who were not involved tend to rate these factors as most relevant compared to the other group. Those already working in the industry said these were less relevant than the other group. These pull factors were of two types: personal factors and work-related factors. In general, working women in the industry suggested that conflict with family $(2.2333 \pm 0.858)$ and childcare responsibilities $(2.4000 \pm 1.037)$ were less relevant among the factors. For the same factors, the non-engaged women rated $1.6000 \pm 0.498$ for conflict with families and $1.5667 \pm 0.0 .568$ for childcare responsibilities. There was a significant difference in the two groups' mean values for childcare responsibilities and lack of experience. Both groups recorded the same mean values for the factor, satisfaction 
about the salary. One interesting feature is the observation of the standard deviation (SD) values. There seems to be a higher variance in the SD values from the women working in the industry than women not working in the industry. Startling deviations were observed in the personal factors of the women who were engaged in the industry. Further, the least deviations were observed in personal factors among those who were not engaged in the industry. But in the work environment factors, people already in the industry showed lesser variance than those not in the industry. This is plausible as regarding the work environment, one group already had the experience, and the other group they do not possess any experience; thus, there may be greater variance in their answers (Knutson \& Schmidgall, 1999; Marinakou, 2014).

Ella is a heritage for the tourism and hospitality industry. Nevertheless, that 30 women not involving the tourism industry can have their reason for non-participation in this industry. Therefore, the researcher asks them through a questionnaire, 'why are you not involved in the tourism and hospitality industry?' There were five reasons included in the questionnaire (Orido, 2017). According to that, most of them (33.3\%) are not involved in tourism industry because of 'language barriers.' The second biggest issue was family conflict. It was 23.3\%. Moreover, $16.6 \%$ of women said lack of knowledge about the tourism industry was the reason that avoids their participation. Furthermore, the same amount (13.3\%) of them said they had no opportunities, and the rest of them said they were not interested in any job. However, out of these 30 women, $53.3 \%$ of them had an idea to involve the tourism and hospitality industry in the future. The rest of them $(46.6 \%)$ had no idea to involve this sector.

\section{Strategies to Improve Local Women Participation in The Hospitality Industry in Ella}

Figure 2 and 3 show the possible strategies to lure more women into the tourism and hospitality industry. Most of them who were engaged in the industry suggest that workshops and training programs (43\%) would be good. This is understandable as those already in the industry know the industry requirements and may need to improve certain skills through this training. Among those who were not involved in the industry suggest that promotional strategies through social media (54\%) would attract more women into the industry. Both the groups think the least effective strategy would be through TV programs. In both cohorts, a considerable number of respondents believe that expanding the jobs in the tourism and hospitality industry would also be an effective strategy to lure more rural women into the industry.

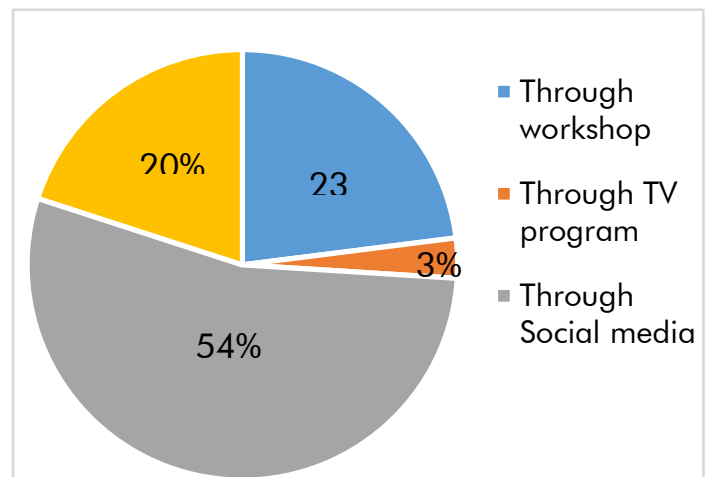

FIGURE 2. OPINION OF THE WORKERS IN THE INDUSTRY

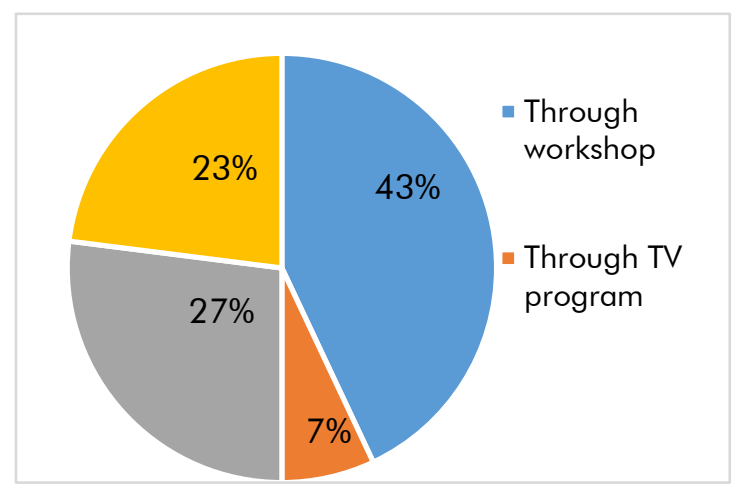

FIGURE 3. OPINION OF NON-WORKERS 
These barriers have been of manifolds for women. Thus, very few women have climbed the career ladder in this industry. An ample amount of flexibility is available for workers in this industry, as formal education is not a barrier. Thus even rural people with less education, including women, can get involved, and they too can decide on their time allocation (Budig, 2006). Some studies have even looked at opportunities for physically impaired people in the industry (Yusoff et al., 2013; Zahari et al., 2010).

Moore (2009) found that discrimination for older women in the industry. It is exacerbated by factors like age, race, and class. Thus older women face occupational and sectoral segregation. Beyond these factors, if the women are from other countries or migrants, the glass ceilings for them are even higher (Janta, 2011). As the migrant women lack knowledge of the local regulations and labor practices adopted, they face further challenges. Another reason was that migrant workers will not be too demanding on work conditions, unlike locals.

Women mostly involve themselves in non-professional and non-managerial selfemployment activities to balance work and family demands (Budig, 2006). This would allow them to maintain a proper balance, whereas if they engage in higher levels of activities, they may have to allocate more time. Greater focus on the job will be demanded as the responsibilities rise. Family factors seem to contribute little to explain women's entrance into professional and managerial self-employment in the hospitality industry.

A considerable amount of studies has dealt with women's employment issues in the tourism and hospitality industry. They have dealt with why women lag behind in the tourism sector (Nayomi \& Gnanapala, 2015; Nyataya \& Ma, 2016) and some specifically on the context of rural women (Malkanthi, Ishana, Sivashankar, \& Weeralal, 2015). What factors lead to these differences in Gender disparity. From agriculture, it has been found that women's contribution to the family is noticeable (Gamhewage, Sivashankar, Mahaliyanaarachchi, Wijeratne, \& Hettiarachchi, 2015; Walpole \& Goodwin, 2000). Thus, in rural areas, women can considerably contribute to the family through tourism activities.

Women take the leading roles in rural tourism (Duarte \& Pereira, 2018). Nevertheless, most of the women are kept out of the institutional system. Past studies also infer that a proper institutional system is needed to empower women (Herawati, Purwaningsih, Pudianti, \& Surya, 2014; Khartishvili et al., 2019; Koutsou et al., 2009; Mohanty et al., 2018; Ramli, Rinanto, Ariyanto, Mafruhah, \& Praseptiangga, 2016). This could be through cooperatives, private enterprises, or even state involvement. Once there is an established system, it is also easy to expel the bad taboo about this industry too. Municipalities could also take up the coordination role. When women are supported by organizations to enter the tourism industry, their income-generating capacity grows and reflects in self-esteem and greater bargaining power (Rinaldi \& Salerno, 2020). Further, institutionalization improves many other skills, including personal and work-related transferable skills, as women get more exposure to other stakeholders (Cvijanović \& Gajić, 2020; Koutsou et al., 2009). 


\section{CONCLUSION}

The main objectives of this research were to understand the important factors affecting and hindering women involvement in Ella DS division's rural tourism activities in restaurants, cafes, and small hotels and examine the effects of the demographic factors such as age, educational level, and marital status on their involvement in such activities. Further, the study measures push and pull factors that affect women's involvement in rural tourism activities. This study also discusses the constraints and provides solutions for these identified constraints. Based on statistical analysis, two hypotheses have been tested.

The study found that women's involvement and non-involvement in the rural hospitality industry can be mainly observed in the age category of 25-29 years older women. When considering these two groups, most of the women are married and have up to secondary education. Most of these women were involved in food \& beverage-related activities in these enterprises. Finally, the study reveals effective communication skills and problem-solving skills had a significant relationship with women's success in the hospitality industry. Child caring responsibilities and lack of experience are the pull factors that hinder women's participation in the tourism and hospitality industry.

Some suggestions can be inferred based on the findings of the study. Since this is an avenue for women to earn an additional income without migrating away from the village, rural tourism can be used as a strategy to alleviate poverty. Establishing day-care centers which would take care of children during working hours would be a solution for the women, as this is a pull factor for them. Further, short training in hospitality management would give these women a chance to cater to the pressing needs of the industry and to improve their language and social capital. This would also aid in removing the traditional mindset of the villagers. As these ventures can cater to both local and foreign tourists, women's involvement in rural tourism should be promoted so as to improve the vulnerable groups who strive below the poverty lines.

\section{REFERENCES}

AlBattat, A. R. S., \& Som, A. P. M. (2013). Employee Dissatisfaction and Turnover Crises in the Malaysian Hospitality Industry. International Journal of Business and Management, 8(5), 62-71. https://doi.org/10.5539/ijbm.v8n5p62

Aslam, M.S.M. and Awang, K.W., (2015). Enterprising rural tourism for sustainable rural development in Sri Lanka. International Journal of Economics and Financial Issues, 5.

Aslam, M. S. M., Awang, K. W., \& Othman, N. B. H. (2014). Issues and Challenges in Nurturing Sustainable Rural Tourism Development. Tourism, Leisure and Global Change, 1, 75-89.

Aytuğ, H. K., \& Mikaeili, M. (2017). Evaluation of Hopa's Rural Tourism Potential in the Context of European Union Tourism Policy. Procedia Environmental Sciences, 37, 234245. https://doi.org/10.1016/j.proenv.2017.03.039 
Budig, M. J. (2006). Intersections on the Road to Self-Employment: Gender, Family and Occupational Class. Social Forces, 84(4), 2223-2239. https://doi.org/10.1353/sof.2006.0082

Chant, S. (2005). Gender and tourism employment in Mexico and the Philippines. In Sinclair, M Thea (Ed.), Gender, Work and Tourism. Routledge advances in tourism. London: Routledge.

Cvijanović, D., \& Gajić, T. (2020). The Level of Engagement of The Female Workforce in The Rural Tourism Development of Serbia. Journal of Tourism, Leisure and Hospitality, 2(1), 36-42.

Duarte, D. C., \& Pereira, A. D. J. (2018). The role of women in rural tourism: a study in the Planaltina's Rajadinha circuit -Federal Districts. Revista Brasileira de Pesquisa Em Turismo, 12(3), 81-102. https://doi.org/10.7784/rbtur.v12i3.1446

Gamhewage, M. I., Sivashankar, P., Mahaliyanaarachchi, R. P., Wijeratne, A. W., \& Hettiarachchi, I. C. (2015). Women participation in urban agriculture and its influence on family economy - Sri Lankan experience. Journal of Agricultural Sciences, 10(3), 192 206. https://doi.org/10.4038/jas.v10i3.8072

Gibbs, L., \& Slevitch, L. (2019). Beyond the classroom: student employability and intention to stay in the hospitality industry. Journal of Teaching in Travel $\mathbb{E}$ Tourism, 19(4), 267284. https://doi.org/10.1080/15313220.2019.1635974

Hafçi, B. (2018). Could Rural Tourism be a Good Generator of Women Workforce?: The Case of Kirazli Town. International Rural Tourism and Development Journal Uluslararast Kirsal Turizm ve Kalkınma Dergisi, 2(2).

Herawati, A., Purwaningsih, A., Pudianti, A., \& Surya, R. V. (2014). Rural Tourism Community Empowerment Based on Local Resources for Improving Community Welfare: Case on Pentingsari Village, Yogyakarta, Indonesia. Review of Integrative Business $\mathcal{E}$ Economi Research (RIBER), 3(2).

Hettiarachchi, I. C., De Silva, D. A. M., \& Sivashankar, P. (2015). Human Resource Audit for the Sri Lankan Tourism and Hospitality Industry. Tourism, Leisure and Global Change, 2, 88-104.

International Labor Organization (2016). Factors affecting women's labour force participation in Sri Lanka. ILO Country Office for Sri Lanka and the Maldives. - Colombo: ILO, 2016. ISBN: $9789221285175 ; 9789221285205$ (web pdf)

Janta, H. (2011). Polish migrant workers in the UK hospitality industry: Profiles, work experience and methods for accessing employmen. International Journal of Contemporary Hospitality Management, 23(6), 803-819. https://doi.org/10.1108/09596111111153484

Khartishvili, L., Muhar, A., Dax, T., \& Khelashvili, I. (2019). Rural Tourism in Georgia in Transition: Challenges for Regional Sustainability. Sustainability, 11(2), 410. https://doi.org/10.3390/su11020410

Knutson, B. J., \& Schmidgall, R. S. (1999). Dimensions of the Glass Ceiling in the Hospitality Industry. Cornell Hotel and Restaurant Administration Quarterly, 40(6), 64-75. https://doi.org/10.1177/001088049904000618 
Koutsou, S., Notta, O., Samathrakis, V., \& Partalidou, M. (2009). Women's Entrepreneurship and Rural Tourism in Greece: Private Enterprises and Cooperatives. South European Society and Politics, 14(2), 191-209. https://doi.org/10.1080/13608740903037968

Malkanthi, S. H. P., Ishana, A. S. F., Sivashankar, P., \& Weeralal, J. L. K. (2015). Willingness to initiate spice-tourism in the Kolonna District Secretariat of Ratnapura district in Sri Lanka: Farmers' perspective. Sri Lanka Journal of Food and Agriculture, 1(1), 35. https://doi.org/10.4038/sljfa.v1i1.5

Marinakou, E. (2014). Women in Hotel Management and Leadership: Diamond or Glass? Journal of Tourism and Hospitality Management, 2(1), 18-25. https://doi.org/10.17265/2328-2169/2014.01.003

Maxwell, G. A., Ogden, S. M., \& Broadbridge, A. (2010). Generation Y’s Career Expectations and Aspirations: Engagement in the Hospitality Industry. Journal of Hospitality and Tourism Management, 17(1), 53-61. https://doi.org/10.1375/jhtm.17.1.53

Milena, P., Nataša, Đ., \& Snežana, M. (2019). Rural tourism in the function of life quality improvement of rural population on Goč mountain. Ekonomika Poljoprivrede, 66(1), 205-220. https://doi.org/10.5937/ekoPolj1901205P

Milicaa, Č., Gordanaa, N., \& Milan, S. (2021). The relation between gender and differences in emotional intelligence of female managers in modern rural tourism. Ekonomika Poljoprivrede, 68(1), 69-83. https://doi.org/10.5937/ekoPolj2101069C

Mohanty, P., Swain, S. K., \& Besra, S. (2018). Women at work: exploring the issues and challenges of women employees in travel and tourism. Indian Journal of Economics and Development, 6(1), 1-5.

Moore, S. (2009). 'No matter what I did I would still end up in the same position': age as a factor defining older women's experience of labour market participation. Work, Employment and Society, 23(4), 655-671. https://doi.org/10.1177/0950017009344871

Nayomi, G. and Gnanapala, W.A., (2015). Socio-economic impacts on local community through tourism development with special reference to Heritance Kandalama. Tourism, Leisure and Global Change, 2(1), pp.57-73.

Nyataya, I. P. K., \& Ma, N. E. K. (2016). Constraints Facing Women's Career Advancement in the Hospitality Industry in Rwanda: Case of Selected Hotels in Kigali. International Journal of Research in Sociology and Anthropology (IJRSA), 2(2), 43-52. https://doi.org/10.20431/2454-8677.0202006

Orido, C. O. (2017). Challenges Faced by Female Chefs in the Kenyan Hospitality Industry: A Study Through an African Oral Tradition of Storytelling (Doctoral dissertation, Auckland University of Technology, Auckland, New Zealand). Retrivied from https://openrepository.aut.ac.nz/handle/10292/10626

Palikhe, A. (2018). Women Empowerment in Tourism: Special Reference to Pokhara Metropolitan City. Journal of Nepalese Business Studies, 11(1), 35-44. https://doi.org/10.3126/jnbs.v11i1.24199 
Ramli, M., Rinanto, Y., Ariyanto, J., Mafruhah, I., \& Praseptiangga, D. (2016). Rural Tourism in Ponorogo East Java Indonesia. Journal of Asian Vocational Education and Training, 9, $52-66$.

Rinaldi, A., \& Salerno, I. (2020). The tourism gender gap and its potential impact on the development of the emerging countries. Quality $\mathcal{E}$ Quantity, 54, 1465-1477. https://doi.org/10.1007/s11135-019-00881-x

Sanagustin-Fons, V., Lafita-Cortés, T., \& Moseñe, J. (2018). Social Perception of Rural Tourism Impact: A Case Study. Sustainability, 10(2), 339. https://doi.org/10.3390/su10020339

Urban Development Authority. (2019). Ella Development Plan 2019-2030 Volume I. Badulla: Urban Development Authority.

Walpole, M. J., \& Goodwin, H. J. (2000). Local economic impacts of dragon tourism in Indonesia. Annals of Tourism Research, 27(3), 559-576. https://doi.org/10.1016/S01607383(99)00088-2

Wang, Y.-F. (2013). Constructing career competency model of hospitality industry employees for career success. International Journal of Contemporary Hospitality Management, 25(7), 994-1016. https://doi.org/10.1108/IJCHM-07-2012-0106

World Bank Group. (2017). Women and Tourism: Designing for Inclusion. Washington, DC: The World Bank Group. from https://documents1.worldbank.org/curated/en/401321508245393514/pdf/120477WP-PUBLIC-Weds-oct-18-9am-ADD-SERIES-36p-IFCWomenandTourismfinal.pdf

World Tourism Organization. (2019). Global Report on Women in Tourism - Second Edition. Madrid: UNWTO. https://doi.org/10.18111/9789284420384

Yusoff, N. M., Zahari, M. S. M., Ahmad, Z., Isa, N. F., \& Ghani, F. A. (2013). Employment Opportunities of The Hearing Impaired in The Hospitality Industry: Gender Analysis. International Journal of Business and Management Studies, 5(1), 368-379.

Zahari, M. S. M., Yusoff, N. M., Jamaluddin, M. R., Radzi, S. M., \& Othman, Z. (2010). The Employability of the Hearing Impaired Graduates in Malaysia Hospitality Industry. World Applied Sciences Journal, 10 (Specia, 126-135. Retrieved from https://www.researchgate.net/publication/228542055\%0A 